\title{
DISKUSSIE
}

\section{Van Wyk se bespreking van my boek: God, waarom lyk die wêreld so?}

\author{
Adrio König \\ Fakulteit Teologie \\ Universiteit van Suid-Afrika \\ PRETORIA
}

E-pos: adk@3gi.co.za

My dank aan Amie van Wyk vir 'n deeglike bespreking van hierdie boek (In die Skriflig, 36(4) 2002). Al sal ek hier en daar vrae vra oor sy beoordeling, het hy dit op 'n waardige vlak gedoen wat reg laat geskied aan die saak. Trouens, hier en daar het hy regtig uit sy pad gegaan om my te probeer verstaan.

Van Wyk maak veel daarvan dat ek 'n nuwe voorsienigheidsleer aanbied (529, 539, 550). Hy meld egter nie dat ek direk en doelbewus by Irenaeus aansluit nie (176-179), iets wat ek vroeër al in 'n boekie oor die versoeningsleer gedoen het (Versoening - Goedkoop? Duur? Verniet? van 1995).

\section{'n Simplistiese weergawe van Calvyn?}

Van Wyk meen dat ek Calvyn "ongenuanseerd en plek-plek selfs simplisties" weergee (541-542). Ek moes volgens hom die hele Calvyn tot sy reg laat kom het: Godsleer, Christologie, Pneumatologie, kommentare, preke, briewe, ensovoorts. Hy wy twee volle bladsye hieraan, maar dui nie aan in watter opsigte Calvyn se siening dan anders daar sou uitgesien het nie.

My vraag is of dit nie volkome verantwoord is om die hoofstukke waarin Calvyn hierdie leer doelbewus en sistematies in sy Institusie behandel het, deeglik na te gaan, en nie sy volkome logiese ontwerp op bepaalde punte aan te pas uit sydelingse opmerkings uit ander bronne waar hy nie doelbewus en sistematies na die saak gekyk het nie. Indien ek gedoen het wat van Wyk vra, sou my gevolgtrekking gewees het dat Calvyn telkens in sy meer insidentele verwysings na die saak inkonsekwent was en sy volkome logiese sisteem deurbreek het. (Dat dit so is, het ek wel in 
die verbygaan genoem.) Het ek dan reg aan Calvyn gedoen? Want dit moet ' $n$ mens goed begryp: Calvyn het in sy doelbewuste behandeling van hierdie leer 'n volkome logiese sisteem aangebied. Ek huiwer om dit te deurbreek in die lig van sy terloopse opmerkings in ander geskrifte.

\section{Calvyn en "toelating"}

Ek het dieselfde vraag oor Van Wyk se kritiek dat ek nie erken dat Calvyn tog in 'n bepaalde sin van die begrip toelating gebruik gemaak het nie (542). Hier gebeur nou presies waarvoor ek bang is as 'n mens sy leer uit los opmerkings probeer nuanseer. In 1.17.11 gebruik Calvyn inderdaad die woord "toelating", maar dit is in 'n konteks waarin hy oorweldigend skryf oor die totale beskikking van God oor alle dinge. Volgens Calvyn kan die duiwel nie 'n vinger verroer om enige misdaad teen ons te pleeg sonder dat God dit gedoog (toelaat), ja, beveel nie. God bewapen die duiwel met woede teen ons. En dan vervolg Calvyn: alles hang van die toelating, ja, die wil van God af. Dit is in hierdie konteks dat hy "toelating" gebruik. En daarom kom hy kort daarna hierop terug (1.18.1) en verwys na sy teenstanders wat liewer van God se toelating as van sy beskikking praat, en dan noem hy "toelating" 'n versinsel. Wanneer hy dan elders 'n paar keer weer die woord gebruik, word dit verduidelik met 'n sterker woord soos "beskik" Is dit nou genuanseerder om te sê Calvyn gebruik tog die woord "toelating"? Die waarheid is dat hy dit ten sterkste afgewys het wanneer dit as alternatief vir beskikking gebruik is - soos deur die Suid-Afrikaanse Calviniste in die 1993-debat.

\section{Kan mooi vroomheid die werklike probleem hanteer?}

Ek het iets van dieselfde probleem met Van Wyk se konklusie in die laaste twee paragrawe van sy bespreking (551). Hy skryf pragtig oor hoe hy die klassieke voorsienigheidsleer verstaan. Dit wou "niks anders sê nie as dat ons elke oomblik in die hande van God is". En dan volg pragtige sinne oor die hand van God wat ons vashou en lei. My vraag: Maar wat beteken dit nou as my enigste dogtertjie deur 'n dronk man doodgery word? En verder: Is dit regtig al wat die klassieke voorsienigheidsleer sê? Waarom dan Calvyn se bladsylange bespreking met 'n volkome logies-sluitende sisteem, insluitend dat God ook alle kwaad beskik, presies soos dit gebeur? Of probeer Van Wyk op 'n oorvereenvoudigde manier iets moois en vertroostends haal uit ' $n$ omvattende teologiese sisteem wat oneindig meer gesê het, insluitend baie perspektiewe waarin 'n liefdevolle God vir baie gelowiges nie meer herkenbaar is nie? 


\section{Onnodig negatief weergegee?}

Hier en daar het ek nogal gewonder of Van Wyk my nie onnodig negatief weergegee het nie. Volgens hom is ek van oordeel dat Calvyn sekere tekste "vermink" (532). Maar ek gebruik mos nie sulke woorde nie. Ek het gemeen dat ek altyd met waardigheid van ander gepraat het. Ek het dit nooit van Calvyn aangeleer om allerlei skelwoorde teen my "teenstanders" te gebruik nie.

Elders (543) bespreek Van Wyk my siening dat daar "'n groot verskeidenheid van gesigspunte oor God se voorsienigheid in die Bybel is". Sy kritiek is dat daar nie "teenstrydige voorsienigheidslere in die Skrif gevind kan word waaruit ons dan die beste moet kies nie". Maar is dit wat ek gesê of geïmpliseer het? Is "verskeidenheid" en "teenstrydigheid" dieselfde? En hoekom impliseer hy dat ek sê die nuwe siening oor die duiwel wat tydens die ballingskap ontwikkel het, is "van die Perse oorgeneem", as ek nie so iets geskryf het nie? En dan sy probleem dat ek kan skryf dat iets in die Bybel "ontwikkel" het. Kan iets nie onder die leiding van die Heilige Gees ontwikkel nie? In dieselfde verband suggereer hy ook dat ek uiteindelik met 'n ander God sit. Ek vind dit vreemd. En waarom skryf Van Wyk (545) dat ek "op 'n kritieke stadium ... tog weer op God se oorweldigende mag moet terugval" as ek in die voorafgaande bladsye (218-229) herhaaldelik en breedvoerig oor God se oorweldigende mag geskryf het, dit direk verbind het aan die skeppingswerk van God, aan die wonderwerke van Jesus en aan sy opstanding, en die volgende woorde in vetdruk: "Dit is nie harde mag óf sagte mag nie. Dit is beide, elkeen op sy plek."

In dieselfde verband verklaar Van Wyk dat God volgens my siening "in 'n proses van magsontplooiing" is. Maar waar het ek ooit so iets geskryf of net begrippe gebruik wat daaraan kan laat dink? Dis mos Prosesteologie.

\section{Van Wyk se eksegese}

Hier en daar het ek nogal huiwering oor Van Wyk se eksegese. Hy vind dit baie jammer dat ek nie Lukas 13:1-5 bespreek het nie. Dit is die voorval waartydens mense vir Jesus kom vertel het van Pilatus wat die Galileërs by hulle offerdiere laat doodmaak het. Melding word ook gemaak van die 18 mense wat deur die toring doodgeval is. Volgens Van Wyk kom "die vraagstuk van kwaad en sonde en sinlose lyding hier uitdruklik ter sprake" (540). Hy vra hoe die aaklige gebeurtenisse verklaar moet word, en vervolg: "By wie lê die skuld? By God? Die duiwel? Die mens?" Uit Christus se antwoord blyk dit dat skuld en straf nie so eenvoudig in mekaar se verlengde lê nie. Maar Christus buig die 
(algemene) waarom- en herkoms-vraag om tot 'n persoonlike waartoeen toekoms-vraag: "As julle julle nie bekeer nie ..."

My vraag hierop is: Kom hierdie vrae oor by wie die skuld lê, regtig hier ter sprake? Kom hulle nie juis nie ter sprake nie? Gaan Jesus nie eerder glad nie op die probleem in nie? En verder, as Calvyn dié vrae moes antwoord, weet ons presies wat sy antwoord in terme van sy amptelike voorsienigheidsleer sou wees: om 'n onbekende goeie rede het God onveranderlik beskik dat Pilatus presies op die regte tyd sy soldate by die offerplek sal hê, en ook dat presies die regte mense wat Hy beskik het om doodgemaak te word, met hul offers sal besig wees, en trouens ook presies hoe elkeen van hulle doodgemaak sal word. En as hulle gelowiges was, kon hulle naasbestaandes getroos wees omdat dit 'n liefdevolle Vader is wat dit tot hul beswil beskik het.

As ek op hierdie vrae sou moes antwoord, sou ek gesê het daar gebeur aaklige dinge téén die wil van God, maar God is so wonderlik dat Hy hierdie tragedie in 'n bekeringsgeleentheid omskep. Maar dan het Calvyn en ook ek ander oogmerke as Jesus gehad in ons reaksie op die voorval.

Nog 'n terloopse eksegetiese opmerking. As Van Wyk na die Bose verwys, maak hy die opmerking dat dit uiters moeilik word as dieselfde gebeurtenis (die volkstelling van Dawid) sowel aan die Here as aan Satan toegeskryf word (2 Sam. 24:1; 1 Kron. 21:1). Ek het altyd gedink dis nie so moeilik nie, solank ons heilshistories dink. Net soos in Job, is daar elders in die vroeë Ou Testament goeie samewerking tussen God en Satan - eenvoudig omdat Satan nog 'n onskuldige "amptenaar" in die hofhouding van die Here was wat sy opdragte gehoorsaam uitgevoer het. Net soos in die geval van Job, sou 'n mens dus ook van die volkstelling kon sê: God, maar ook Satan. God beveel Satan, of laat Satan toe, en Satan doen dit.

Maar genoeg aan kleiner besonderhede. Ondanks sekere vrae meen ek dat Van Wyk inderdaad probeer het om my te verstaan en redelik weer te gee. En ek sê weer dankie.

\section{Onkonvensionele woorde soos "God ly neerlae"}

En nou wat die groot sake betref. Ek het hoë waardering vir baie aspekte van Calvyn se teologie. Dink maar aan sy regverdigingsleer. Ek meen maar net dat hy in sy voorsienigheidsleer nie die Skrif tot sy reg laat kom het nie. Miskien het ek een sentrale ding probeer doen: om vir gelowiges wat in rou gedompel is te sê: Moenie so maklik aanvaar dit is God wat julle in die rou gedompel het nie. Trouens, Hy is in julle rou by julle, en 
Hy sal julle help om weer sin van julle lewe te maak. Hou aan Hom vas. Hy sal julle help om nog sterker anderkant uit te kom.

Om hierdie doel te bereik, het ek baie dinge geskryf, sommige wat Van Wyk met huiwering vervul. Ek huiwer self oor sommige dinge, maar ek meen tog dat ek dit in die Bybel kry, en daarom die verantwoordelikheid het om dit te probeer formuleer. Op die ou end is dit tog ook nie ons emosies wat die deurslag behoort te gee nie. Ek meen dat daar hoofsaaklik twee moontlikhede is om die groot lyne van die heilsgeskiedenis te verstaan: óf soos Calvyn dat God alles tot in die kleinste detail presies so voorbeskik het soos dit plaasvind, óf dat God sterk teenstand kry van bose magte en mense, en nie altyd alles wat Hy wil, dadelik regkry nie. As God alles wat Hy wil, dadelik regkry, moet jy my nie vra hoekom die wêreld in so 'n toestand is nie, en ook nie hoekom my lewe so ver onder sy eise en standaarde is nie.

Hierdie siening bring egter minstens twee sake na vore wat Van Wyk met huiwering vervul. Daar staan sinne in die boek soos: "God kan nie", en "God ly soms neerlae". Ek het nie twyfel dat dit meer mense laat huiwer nie. Ekself ook. Maar kom ons oorweeg dit net 'n oomblik.

Dat God nie kan nie, is nie so 'n vreemde uitdrukking in die teologie en filosofie nie. Logies gesproke, kan God nie dinge doen wat teenstrydig is nie, soos 'n vierkantige sirkel maak of 'n klip maak wat so swaar is dat Hy dit nie kan optel nie. Eties gesproke, kan Hy nie doen wat teen sy wese is nie (sondig). Histories gesproke, kan Hy nie die geskiedenis verander sodat Israel nooit aan Hom ontrou was, daar trouens nooit 'n sondeval was, en Christus nooit aan die kruis gesterf het nie. Teologies gesproke, kan God volgens Calvyn niks verander aan die ewige beslissings wat Hy eenmaal gemaak het van presies hoe alles altyd sal verloop nie. En hierdie laaste saak is natuurlik omvattend en ingrypend. God het eenmaal besluit oor alles, en kan nooit weer anders daaroor besluit nie, en kan ook nooit anders handel as wat Hy eenmaal in die ewigheid besluit het nie.

Is dit regtig so ongehoord om te sê God kan nie? Is dit nie waar dat God nie vir Israel gehoorsaam aan Hom kon kry nie? Wat sê die meerderheid bladsye in die Profete anders? Ons het 'n keuse. Ons sê dit so, of ons sê God wou hulle maar net volgens sy geopenbaarde wil aan Hom gehoorsaam hê, maar volgens sy verborge wil wou Hy hê, en het Hy trouens onveranderlik bepaal, dat hulle aanhoudend ongehoorsaam aan Hom sou wees. Ek het nie twyfel oor hoe ek die Profete op hierdie punt moet verstaan nie, al is dit huiweringwekkend om te aanvaar dat God regtig probeer het, maar nie kon nie. Die alternatief is "too ghastly to contemplate": sy geopenbaarde wil is nie sy eintlike wil nie. Sy eintlike 
wil is verborge en ons moet maar in die onbekende rondtas oor wat $\mathrm{Hy}$ regtig wil, ondanks die duisend bladsye Bybel.

Die tweede gewraakte uitspraak hang hiermee saam: God ly soms neerlae. Ek erken dit is onkonvensionele taal. Dit is inderdaad nie die manier waarop ons gewoonlik oor God dink nie. Verder sou 'n mens seker 'n "sagter" woord kon soek. Maar wat kry ons anders in die Profete? As ons die Bybel, die geopenbaarde wil van God ernstig neem, wat wou Hy anders as dat Israel getrou en gehoorsaam aan Hom sou wees? En was hulle? Wat anders kan ons dit noem wat Hy eeue lank in hierdie situasies ervaar het? In Jeremia 2 roep $\mathrm{Hy}$ in die grootste frustrasie uit. Kyk weer na vers 12. Is "hemel" iets anders as 'n eufemisme vir God self? Sal dit help as ons hierdie pynlike hoofstuk in suikerklontjies toemaak: "God praat maar net mensvormig anders sou ons nie kon verstaan het nie." "God wil maar net die erns van ons sonde beklemtoon"?

\section{Samevatting}

Dit is waar dat ek 'n alternatief op die voorsienigheidsleer van Calvyn en Arminius probeer stel het. Ek maak dankbaar gebruik van die model van stryd en oorwinning wat Irenaeus vir die versoeningsleer gebruik het. Ek meen dit help gelowiges om nie hul leed en smart so maklik aan God toe te skryf en dikwels in erge geloofsprobleme te beland by die gedagte dat 'n liefdevolle Vader dit aan hulle gedoen het (Calvyn) of dit toegelaat het nie (Arminius). Dit maak ruimte daarvoor dat ons in 'n harde werklikheid leef waarin vreeslik baie dinge téén die wil van God gebeur, maar dit bied die troos dat die Here beloof het om by ons te wees in ons nood, en versterk die vooruitsig na die wederkoms van Christus en na die nuwe aarde waar "alles sal reg wees". 